\title{
ERRATUM
}

Open Access

\section{Erratum to: Reassessment of the development and hazard of the Rampac Grande landslide, Cordillera Negra, Peru}

Vít Vilímek ${ }^{1 *}$, Jan Klimeš ${ }^{2}$ and Marco Zapata Torres ${ }^{3}$

\section{Erratum}

Geoenvironmental Disasters 2016 3:5 DOI: 10.1186/ s40677-016-0039-8

Unfortunately, the original version of this article (Vilímek et al. 2016) contained an error in the third author's name and affiliation. The correct authors name and affiliation is the following:

Marco Zapata Torres (National University of San Marcos, Calle Gemán Amézaga 375, Lima 1, Peru)

\section{Author details}

'Department of Physical Geography and Geoecology, Faculty of Science, Charles University, Albertov St. 6, Prague 2128 43, Czech Republic. Institute of Rock Structure and Mechanics, Academy of Sciences, V Holešovičkách 41, Prague 8182 09, Czech Republic. ${ }^{3}$ National University of San Marcos, Calle Gemán Amézaga 375, Lima 1, Peru.

Received: 9 June 2016 Accepted: 10 June 2016

Published online: 20 September 2016

\section{Reference}

Vilímek, Vit, Jan Klimeš, and Marco Zapata Torres. 2016. Reassessment of the development and hazard of the Rampac Grande landslide, Cordillera Negra, Peru. Geoenvironmental Disasters 3: 5 .

\footnotetext{
* Correspondence: vit.vilimek@natur.cuni.cz

'Department of Physical Geography and Geoecology, Faculty of Science, Charles University, Albertov St. 6, Prague 2128 43, Czech Republic
}

Submit your manuscript to a SpringerOpen ${ }^{\circ}$ journal and benefit from:

- Convenient online submission

- Rigorous peer review

- Immediate publication on acceptance

- Open access: articles freely available online

- High visibility within the field

- Retaining the copyright to your article

Submit your next manuscript at springeropen.com 